\title{
Relationship between Abdominal Obesity and Prostate Specific Antigen Level
}

\author{
Chae-I Lim ${ }^{1}$ and Yun-Jung Kang ${ }^{2}$ \\ ${ }^{1}$ Department of Health Promotion Center, The Catholic University of Korea ST., Vincent Hospital, Suwon 442-723, Korea \\ ${ }^{2}$ Department of Health Science, Dankook University Graduate School, Cheonan 330-714, Korea
}

\begin{abstract}
This paper presents an investigation into factors influencing the level of prostate specific antigens (PSAs) in men with a focus on abdominal obesity. Data were collected from the exam results and medical records of male clients that visited a university hospital in Suwon for a general check-up. The data of total 1,039 were put to frequency analysis, descriptive statistics, independent-sample t-test, one-way ANOVA, chi-squared test, and multiple regression analysis. The subjects were men in their twenties to in their seventies. The study analyzed whether there would be differences in mean PSAs according to the characteristics of the subjects and found significant differences according to age, BMI, and waist. The findings indicate that abdominal obesity influences the level of PSAs in men and that men with abdominal obesity should not neglect the level of PSAs even in the normal range.
\end{abstract}

Keywords: Abdominal obesity, BMI, PSA level

This is an Open Access article distributed under the terms of the Creative Commons Attribution Non-Commercial License (http://creativecommons.org/licenses/by-nc/3.0) which permits unrestricted non-commercial use, distribution, and reproduction in any medium, provided the original work is properly cited.

Copyright @ 2015 The Korean Society for Clinical Laboratory Science. All rights reserved.
Corresponding author: Yun-Jung Kang Department of Health Science, Dankook University Graduate School, Cheonan 330-714, Korea Tel: 82-31-683-2901

E-mail: yun_jung83@hanmail.net

Received: February 27, 2015

Revised: March 17, 2015 Accepted: March 18, 2015

\section{서 론}

비만은 세계적으로 높은 관심을 받을 정도로 심각한 문제이며 세계보건기구에서 질병으로 규정하고 있다. 우리나라 또한 사회적 변화에 따라 식생활이 서구화되고 활동량 감소 등으로 비만의 유병 률이 급속도로 증가하고 있다. 2012년 국민영양조사에 따르면 우 리나라 비만 유병률(만 19세 이상)은 체질량지수 $25 \mathrm{~kg} / \mathrm{m}^{2}$ 이상인 비만인구가 $32.8 \%$ (남자는 $36.1 \%$, 여자는 $29.7 \%$ )로 남자가 여자 보다 높았고, 2005년도 조사와 비교하여 증가하고 있음을 보여준 다. 세계보건기구(2002)는 비만이란 '지방 조직이 건강에 이상을 초래할 정도로 과잉 축적된 상태'라 정의하였다. 신 등(2013)의 연 구결과에서 복부비만을 동반한 비만군에서 느린 심박수 회복반응 을 보였으며, 심박수 회복은 체질량지수, 체지방량, 허리둘레와 음 의 상관관계를 보였다. 이는 대사증후군에서 허리둘레가 증가할수 록 느린 심박수 회복을 보인다는 것을 의미한다. 또한 비만은 당뇨, 고지혈증, 고혈압 등을 증가시키고 심근경색, 뇌졸중, 암 등 질환을 초래하여 조기사망 원인이 된다(Freedland 등, 2005)는 보고들이 있다. 이러한 질병의 예방과 효과적 관리를 위해 비만을 정확하게
평가하는 것이 중요한데, 비만 판정 지표는 현재 '체질량지수(Body mass index; BMI, 이하 BMI)'가 가장 많이 사용 되고, 우리나라는 $\mathrm{WHO}$ 서태평양지역회의에서 정의한 기준을 따라 체질량지수 (BMI) $23 \mathrm{~kg} / \mathrm{m}^{2}$ 이상을 과체중으로, $25 \mathrm{~kg} / \mathrm{m}^{2}$ 이상을 비만으로 사 용하고 있다. 그런데 체질량지수(BMI) $25 \mathrm{~kg} / \mathrm{m}^{2}$ 미만이라 하더라 도 허리둘레가 표준보다 굵은 비만일 경우 비만 관련 질환 및 여러 합병증 발생 위험이 증가하고 심한 경우 심혈관 질환 및 만성질환 이 증가로 나타나 전체적인 단순 비만으로 보는 BMI 결과보다 복부 비만 평가의 중요성이 강조되고 있다(박혜순 등, 2003; 이호진 등, 2004; 박승국 등, 2010). 비만과 더불어 암 또한 중대한 관심사인데 남성들의 전립샘암은 눈에 띄게 증가하여 미국에서는 남성 종양중 발병률 1 위, 종양 사망률 2위이며 마찬가지로 우리나라도 종양 중 에 발병률 5위(국가암정보센터, 2011)에 이르고 있다. 이러한 남성 의 전립샘암은 위암과 더불어 조기발견 후 수술적 치료를 하는 경 우에 거의 완전한 치료에 가까운 효과를 기대할 수 있기 때문에 조 기발견이 매우 중요한 역할을 한다(Ohori M 등, 1994). 현재 전 립샘암을 선별하는데 혈중 전립샘특이항원(Prostate-specific antigen; PSA)이 사용되어지고 있고, 이는 전립샘암 뿐만 아니라 
전립샘비대증, 전립샘염 등의 전립샘 질환의 선별진단에 사용되고 있다.

현재 비만과 전립샘암이 높은 유병률로 두 질환에 대한 연관성 연구가 활발하게 이루어지고 있는 가운데(손지철 등, 2007; 윤창준 등, 2005) 비만의 지표가 단순히 BMI가 아닌 허리둘레, 허리 엉덩 이 둘레 비(이하 WHR), 내장지방 표면적(이하, VFA) 등의 복부비 만 지표와 전립샘암의 선별검사인 전립샘특이항원과의 연관성에 대하여 조사하여 비만한 남성들에게서의 전립샘특이항원으로 보 는 전립샘 관련 질병 예방관리에 도움이 되고자 한다.

\section{재료 및 방법}

\section{1. 연구대상}

본 연구에서는 2013년도 한 해 동안 수원시 소재 대학병원 건강 증진센터에서 종합검진 수검자들 중 전립샘특이항원 검사를 시행 한 남성을 대상으로 하였다. 대상자 중 전립샘암, 전립샘비대증, 전 립샘염 등 전립샘 관련 질환을 진단받은 환자와 전립샘 관련 약 복 용 중인 환자, 하부요로 염증 등 불편을 호소하여 비뇨기과 방문 치 료 중인 환자를 제외한 1,039 명을 분석 대상으로 하였다.

\section{2. 연구방법}

1) 전립샘특이항원(Prostate specific antigen, PSA)

전립샘특이항원은 전립샘의 상피세포에서 합성되는 정상적인 단백분해 효소로 전립샘 이외의 조직에서는 거의 발현되지 않아 전 립샘암의 선별에 이용되는 유용한 종양표지자이다. 하지만 전립샘 특이항원는 전립샘 조직에는 특이적이지만 종양에는 특이적이지 않아 전립샘비대증, 전립샘염, 전립샘경색 등에서도 증가할 수 있 다. 전립샘특이항원는 전립샘암의 선별 검사뿐만 아니라 수술 후 재발 판정에도 유용하게 이용할 수 있다. 전립샘특이항원의 참고치 는 일반적으로 0 4 $\mathrm{ng} / \mathrm{mL}$ 이다. 하지만 선별 검사의 민감도, 특이 도를 높이기 위하여 나이 대에 따라 다른 참고치를 적용할 수도 있 다.

전립샘특이항원수치 분석으로는 SST $5 \mathrm{~mL}$ vacutainer 튜브 (Sekisui Chemical Co, Osaka, Japan)로 채혈한 혈액을 2시간 이내 혈청분리 후 ARCHITECT I2000을 이용하여 2-step 화학 발광 면역분석법(CMIA; Chemiluminescent microparticle immunoassay)으로 측정하였다. Chemiflex라고 하는 flexible assay protocol과 CMIA 테크놀러지를 사용한다. 첫번째 단계에서 sample과 Anti-PSA가 코팅된 paramagnetic microparticles (상자성 미립자)이 반응한다. 검체에 전립샘특이항원가 있다면 Anti-PSA가 코팅된 microparticle과 결합을 하고 washing단계를
거친 후, 두번째 단계에서 conjugate (anti- PSA acridinium labeled)를 첨가한다. 다시 washing단계 후에 Pre-trigger와 trigger solution이 첨가 된다. chemiluminescent (화학 발광) 반 응 결과는 상대적인 빛 단위(Relative light units)로 측정이 된다.

\section{2) 비만}

비만은 체지방의 과잉 축적 상태이다. 비만 환자의 건강 위험도 를 평가하고 치료 기준을 마련하기 위해서는 체지방 측정을 통한 적절한 비만도의 평가가 중요하다. 임상에서는 저렴하고 측정이 간 편한 신체계측법과 생체전기임피던스 분석법이 비만도 측정을 위 해 흔히 이용되고 있다. 비만을 진단하기 위해 현재 가장 보편적으 로 사용되는 기준은 체질량지수(Body mass index; BMI)이다(전 영선, 2006).

본 연구에서는 8 시간 이상 금식상태, 운동을 하지 않은 상태에서 신발과 양말, 모자 등을 벗고 표시된 발 위치에 바른 자세로 서서 부 위별 직접측정법(Direct Segmental Measurement Bioelectrical Impedance Analysis Method, DSA-BIA방식, InBody720, (주)인 바디)으로 측정하였으며, 아시아-태평양지역 기준을 적용하여 BMI $18.5 \mathrm{~kg} / \mathrm{m}^{2}$ 이하를 정상, BMI $23 \sim 24.9 \mathrm{~kg} / \mathrm{m}^{2}$ 를 과체중, BMI $25 \mathrm{~kg} / \mathrm{m}^{2}$ 이상을 비만으로 분류하였다.

\section{3) 복부비만}

복부비만이란 신체가 함유하고 있는 지방의 비율이 정상보다 높 은 복부상태, 즉, 제지방에 비하여 상대적으로 피하조직 및 기타 조 직에 지방이 과잉 축적된 상태라고 정의할 수 있다. 복부비만 판정 은 간단히 측정이 가능하면서도 내장지방 및 심혈관 질환의 위험을 가장 잘 반영하는 지표로 인정되고 있다. 복부비만을 진단하는 허 리둘레의 분별점은 인종, 성별에 따라 다르게 적용하는 추세이며, 국내에서 복부비만의 진단 기준은 2006년까지 세계보건기구아시 아-태평양지역의 복부비만 기준치를 따라 남자에서 $90 \mathrm{~cm}$ 이상이 다. 허리둘레 측정 시 표준화된 해부학적 위치의 선정은 매우 중요 하다. $\mathrm{WHO}$ 에서 제시한 방법은 양발 간격을 $25 \sim 30 \mathrm{~cm}$ 정도 벌리 고 서서 체중을 균등히 분배시키고, 숨을 편안히 내쉰 상태에서 줄 자를 이용하여 측정한다. 측정 위치는 최하위늑골하부와 골반장골 능과의 중간부위를 측정하며, 이는 전상장골극(Anterior superior iliac spine)의 $3 \mathrm{~cm}$ 상부 쪽을 의미한다. 측정 시에는 줄자가 연부 조직에 압력을 주지 않을 정도로 느슨하게 하여 $0.1 \mathrm{~cm}$ 까지 측정한 다. 심한 비만인 경우나 출산 후, 폐경 후 여성에서는 피하지방이 과 도하여 허리와 겹쳐져 실제보다 길게 측정되는 경우가 있다. 이러 한 경우에는 직립자세에서 피하지방을 들어 올려 측정하는 것을 원 칙으로 한다(대한비만학회, 2009). 
본 연구에서는 허리둘레는 $\mathrm{WHO}$ 에서 제시한 방법으로 줄자를 이용하여 측정하였고, WHR (허리-엉덩이둘레비)과 VFA (내장지 방표면적)는 발 위치에 바른 자세로 서서 부위별 직접측정법 (Direct Segmental Measurement Bioelectrical Impedance Analysis Method, DSA-BIA방식, InBody720, (주인바디)으로 측 정하였다. 허리둘레 $90 \mathrm{~cm}$ 이상, WHR 0.9 이상, VFA 100 이상을 복부비만으로 분류하였다.

\section{3. 자료의 분석}

수집한 데이터는 윈도우용 SPSS 19.0 version을 사용하였으며, 일반적 특성에 따른 빈도분석 및 대상자 특성에 따른 전립샘특이항 원 수치를 보고자 독립표본 t검정과 일원배치분산 분석, 복부비만 이 전립샘특이항원 수치에 미치는 영향력을 파악하기 위한 다중 회 귀분석을 실시하였다.

\section{결 과}

\section{1. 대상자의 연령분포와 비만수준}

전체대상자 중 50 59세가 $34.6 \%$ 로 가장 많았으며, $40 \sim 49$ 세 (26.4\%), 30세 이하(20.4\%), 60 69세 (13.0\%), 70세 이상 $(5.7 \%)$ 순이었다.

비만은 비만과 복부비만으로 나누어 확인하였다. BMI는 23 $\mathrm{kg} / \mathrm{m}^{2}$ 미만과 23 24.9 kg/m²는 각각 279 (26.9\%)명과 276 (26.6\%)명으로 크게 차이가 없었고 $25 \mathrm{~kg} / \mathrm{m}^{2}$ 이상은 484 명으로 전체 $46.6 \%$ 를 차지하였다. 체지방률로 비교 시 $20 \%$ 이하는 197 명, $20 \%$ 초과되는 사람은 842 명으로 두 부류가 큰 차이를 보였다. 복 부비만은 허리둘레, WHR, VFA로 보았고 대표적으로 사용하고 있

Table 1. Subjects of age and obesity levels

\begin{tabular}{|c|c|c|c|c|}
\hline \multicolumn{3}{|c|}{ Variables } & \multirow{2}{*}{$\frac{N}{212}$} & \multirow{2}{*}{$\begin{array}{c}\% \\
20.4\end{array}$} \\
\hline Age & & $\leqq 39$ & & \\
\hline & & $40 \sim 49$ & 274 & 26.4 \\
\hline & & $50 \sim 59$ & 359 & 34.6 \\
\hline & & $60 \sim 69$ & 135 & 13.0 \\
\hline & & $\geqq 70$ & 59 & 5.7 \\
\hline \multirow[t]{5}{*}{ Obesity } & \multirow[t]{3}{*}{ BMI } & $<23 \mathrm{~kg} / \mathrm{m}^{2}$ & 279 & 26.9 \\
\hline & & $23 \sim 24.9 \mathrm{~kg} / \mathrm{m}^{2}$ & 276 & 26.6 \\
\hline & & $\geqq 25 \mathrm{~kg} / \mathrm{m}^{2}$ & 484 & 46.6 \\
\hline & \multirow[t]{2}{*}{ BMI (\%) } & $\leqq 20 \%$ & 197 & 19.0 \\
\hline & & $<20 \%$ & 842 & 81.0 \\
\hline \multirow{6}{*}{$\begin{array}{l}\text { Abdominal } \\
\text { Obesity }\end{array}$} & \multirow{2}{*}{$\begin{array}{l}\text { Waist } \\
\text { circumference }\end{array}$} & $<90 \mathrm{~cm}$ & 638 & 61.4 \\
\hline & & $\geqq 90 \mathrm{~cm}$ & 401 & 38.6 \\
\hline & \multirow[t]{2}{*}{ WHR } & $<0.90$ & 377 & 36.3 \\
\hline & & $\geqq 0.90$ & 662 & 63.7 \\
\hline & \multirow[t]{2}{*}{ VFA } & $<100 \mathrm{~cm}^{2}$ & 284 & 27.3 \\
\hline & & $\geqq 100 \mathrm{~cm}^{2}$ & 755 & 72.7 \\
\hline
\end{tabular}

는 허리둘레를 보았을 때, $90 \mathrm{~cm}$ 미만은 $638(61.4 \%)$ 명, $90 \mathrm{~cm}$ 이 상은 401 (38.6\%)명 이었다. WHR은 0.9를 기준으로 미만은 377 (36.3\%)명, 이상은 662명으로 63.7\%를 차지하였으며 VFA는 100 $\mathrm{cm}^{2}$ 미만이 $284(27.3 \%)$ 명, $100 \mathrm{~cm}^{2}$ 이상이 755 (72.7\%)명 이었 다(Table 1).

\section{2. 대상자 특성에 따른 전립샘특이항원 수치}

\section{1) 연령에 따른 전립샘특이항원 수치}

연령에 따른 전립샘특이항원 수치의 평균값에 차이가 있는지 보 기 위해 일원배치분산분석(one-way ANOVA)를 실시하였고, 분 석 결과 연령이 증가함에 따라 전립샘특이항원 수치가 유의하게 증 가하는 것으로 나타났다( $\mathrm{F}=6.317, p<0.001$ ) (Table 2).

\section{2) 비만지표에 따른 전립샘특이항원 수치}

비만지표에 따라 전립샘특이항원 수치의 평균값에 차이가 있는 지 알아보기 위해서 일원배치분산분석(one-way ANOVA)과 독립 표본 t검정(independent samples t-test)을 실시하였고, 분석 결 과 $\mathrm{BMI}$ 는 $23 \mathrm{~kg} / \mathrm{m}^{2}$ 미만(0.98584)의 경우 전립샘특이항원 수치가 가장 높았고, 다음은 $25 \mathrm{~kg} / \mathrm{m}^{2}$ 이상 $(.87903)$ 이었으며, 가장 낮 은 수치는 $23 \sim 24.9 \mathrm{~kg} / \mathrm{m}^{2}$ (0.87727)으로 나타났다(F=3.487, $p<0.05)$. 그러나 사후검정 결과에서는 전립샘특이항원 수치에 따 른 집단 간 유의한 차이는 나타나지 않았다. 체지방률 $20 \%$ 를 기준 으로 비교하였으나 두 부류의 전립샘특이항원 수치에 유의한 차이 가 없는 것으로 나타났다. 허리둘레는 $90 \mathrm{~cm}$ 미만(0.94195)이 90 $\mathrm{cm}$ 이상(0.85203)보다 전립샘특이항원 수치가 높은 것으로 나타 났다 $(\mathrm{t}=2.427, p<0.05)$. WHR과 VFA는 각각 0.9 와 $100 \mathrm{~cm}^{2}$ 기준 으로 비교하였으나 두 부류의 전립샘특이항원 수치에 유의한 차이 가 없는 것으로 나타났다(Table 3).

\section{3. 체질량지수와 허리둘레 여부 관계 카이제곱 분석}

체질량지수와 허리둘레의 연관성을 알아보기 위하여 BMI 23 $\mathrm{kg} / \mathrm{m}^{2}$ 미만과 BMI $23 \mathrm{~kg} / \mathrm{m}^{2}$ 이상, 허리둘레 $90 \mathrm{~cm}$ 미만과 $90 \mathrm{~cm}$ 이상으로 카이제곱검정(chi-square test)을 실시하였으며, 분석결 과 $\mathrm{BMI}$ 수준과 허리둘레 수준에는 통계적으로 유의한 연관성이 있

Table 2. The prostate specific antigen levels according to age

\begin{tabular}{lrcccc}
\hline \multicolumn{1}{c}{ Age } & $\mathrm{N}$ & Mean $(\mathrm{ng} / \mathrm{mL})$ & $\mathrm{SD}$ & $\mathrm{F}$ & $p$ \\
\hline$\leqq 39$ & 212 & 0.82317 & .460152 & 6.317 & $.000^{\star * *}$ \\
$40 \sim 49$ & 274 & 0.83391 & .494905 & & \\
$50 \sim 59$ & 359 & 0.94319 & .598202 & & \\
$60 \sim 69$ & 135 & 0.97344 & .685607 & & \\
$\geqq 70$ & 59 & 1.17969 & .844802 & & \\
\hline
\end{tabular}

${ }^{* * \star} p<0.001$. 
14 Chae-I Lim and Yun-Jung Kang. Abdominal Obesity and Prostate Specific Antigen Level

Table 3. The prostate specific antigen levels according to obesity index

\begin{tabular}{|c|c|c|c|c|c|c|}
\hline \multicolumn{2}{|c|}{ Variables } & \multirow{2}{*}{$\frac{N}{279}$} & \multirow{2}{*}{$\frac{\text { Mean }(\mathrm{ng} / \mathrm{mL})}{0.98584}$} & \multirow{2}{*}{$\frac{\text { SD }}{0.638108}$} & \multirow{2}{*}{$\frac{F \text { or } t}{3.487}$} & \multirow{2}{*}{$\frac{p}{0.031^{*}}$} \\
\hline $\mathrm{BMI}$ & $<23 \mathrm{~kg} / \mathrm{m}^{2}$ & & & & & \\
\hline & $23 \sim 24.9 \mathrm{~kg} / \mathrm{m}^{2}$ & 276 & 0.87727 & 0.490959 & & \\
\hline & $\geqq 25 \mathrm{~kg} / \mathrm{m}^{2}$ & 484 & 0.87903 & 0.594316 & & \\
\hline \multirow[t]{2}{*}{ BMI (\%) } & $<20 \%$ & 197 & 0.96032 & 0.596281 & -1.416 & 0.157 \\
\hline & $\geqq 20 \%$ & 842 & 0.89491 & 0.579159 & & \\
\hline \multirow[t]{2}{*}{ Waist circumference } & $<90 \mathrm{~cm}$ & 638 & 0.94195 & 0.597451 & -2.427 & $0.015^{*}$ \\
\hline & $\geqq 90 \mathrm{~cm}$ & 401 & 0.85203 & 0.554694 & & \\
\hline \multirow[t]{2}{*}{ WHR } & $<0.90$ & 377 & 0.89116 & 0.550195 & 0.671 & 0.502 \\
\hline & $\geqq 0.90$ & 662 & 0.91640 & 0.600639 & & \\
\hline \multirow{2}{*}{ VFA } & $<100 \mathrm{~cm}^{2}$ & 284 & 0.94808 & 0.591491 & -1.386 & 0.166 \\
\hline & $\geqq 100 \mathrm{~cm}^{2}$ & 755 & 0.89188 & 0.579007 & & \\
\hline
\end{tabular}

${ }^{*} p<0.05$.

Table 4. BMI and waist level association levels

\begin{tabular}{cccc}
\hline & \multicolumn{2}{c}{ Waist circumference } \\
\cline { 2 - 3 } & & $<90 \mathrm{~cm}$ & $\geqq 90 \mathrm{~cm}$ \\
\hline \multirow{2}{*}{$\mathrm{BMI} \quad<23 \mathrm{~kg} / \mathrm{m}^{2}$} & $272(26.18 \%)$ & $7(0.67 \%)$ \\
& $\geqq 23 \mathrm{~kg} / \mathrm{m}^{2}$ & $366(35.23 \%)$ & $394(37.92 \%)$ \\
\hline
\end{tabular}

는 것으로 나타났다 $\left(\mathrm{x}^{2}=209.578, p<0.001\right) . \mathrm{BMI}$ 가 $23 \mathrm{~kg} / \mathrm{m}^{2}$ 미 만인 경우, 허리둘레가 $90 \mathrm{~cm}$ 미만은 $272(97.5 \%)$ 명, $90 \mathrm{~cm}$ 이상 은 7 (2.5\%)명이고, BMI가 $23 \mathrm{~kg} / \mathrm{m}^{2}$ 이상인 경우 허리둘레가 90 $\mathrm{cm}$ 미만은 366 (48.2\%)명, $90 \mathrm{~cm}$ 이상은 394 (51.8\%)명이다 (Table 4).

\section{BMI와 허리둘레가 전립샘특이항원 수치에 미치는 영향}

첫 번째는 나이와 BMI를 투입하였으며 두 번째로 나이와 허리둘 레를 투입하여 확인하였다.

첫 번째, 나이와 BMI를 투입하였고 둘의 상호작용은 없었으며 모형은 통계적으로 유의하였다( $\mathrm{F}=14.911, p<0.001)$. 독립변수 의 상대적 기여도에 의하면 나이 $(\mathrm{t}=4.764, p<0.001)$ 가 $\mathrm{BMI}$ $(\mathrm{t}=-2.879, p<0.05)$ 보다 전립샘특이항원 수치에 유의하게 증가 하였다(Table 5).

두 번째, 나이와 허리둘레를 투입하였고 첫 번째와 같이 상호작용 은 없었으며 모형은 통계적으로 유의하였다. $\mathrm{F}=14.948, p<0.001)$. 독립변수의 상대적 기여도에 의하면 나이 $(\mathrm{t}=4.886, p<0.001)$ 가 허리둘레 $(\mathrm{t}=-2.897, p<0.05)$ 보다 전립샘특이항원 수치에 유의 하게 증가하였다(Table 5).

\section{고 찰}

서구화된 식습관과 생활패턴으로 비만환자들은 급증하고 있고 그로인해 동반 질환 이환율의 증가도 함께하고 있다. 비만은 여러
Table 5. The effects of BMI, waist circumference on the prostate specific antigen levels

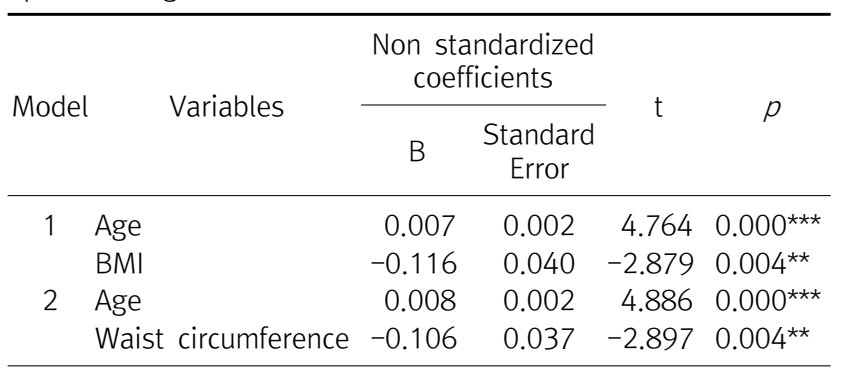

${ }^{\star \star} p<0.01,{ }^{* * *} p<0.001$.

연구들을 통해 뇌혈관질환, 고혈압, 당뇨 등 위험을 직접적으로 증 가시킨다고 알려져 있고 고지방 식이를 함으로서 유방암과 직장암 의 위험도 증가시킨다(Bray 등, 2002). 특히 복부비만은 비만 관련 질환 및 여러 합병증 발생 위험이 증가하고 심한 경우 심혈관 질환 및 만성질환이 증가로 나타나 복부비만 평가의 중요성이 강조되고 있다(박혜순 등, 2003; 이호진 등, 2004; 박승국 등, 2010). 전립샘 특이항원 수치는 전립샘암을 진단하거나 전립샘암 예후 판정에도 유용하게 쓰이고 있다. 그러나 이런 전립샘특이항원 수치는 전립샘 질환 외 많은 요인들의 영향을 받을 수 있어 전립샘특이항원 검사 의 정확성에 대해 끊임없이 논의가 되고 있다. 전형진 등(2006)은 특별한 과거력이 없는 정상 성인에서 혈중 전립샘특이항원에 영향 을 미치는 가장 중요한 요인은 나이와 인종이라고 하였고, 120,439 명의 우리나라 정상인의 연령별 전립샘특이항원의 수치를 확인한 결과 나이가 증가함에 따라 유의한 증가를 나타나는 결과를 보였으 며. 이무주 등(2001)의 연구에서도 30대에서 50대까지는 통계학 적으로 차이가 없었으나, 60 세 이후에는 유의하게 증가된 결과를 보였다. 또한 나이가 들어감에 따라 전립샘특이항원수치가 일정하 게 증가하는 것이 아니라 연령대에 따라 증가 추세가 상승하는 결 과를 보였다. 이러한 내용은 본 연구의 연령대에 따른 전립샘특이 항원수치 비교 시와 동일하다. 전립샘특이항원의 생성은 남성호르 
몬의 영향 하에 있고 남성호르몬의 활동 감소로 인해 혈청 전립샘 특이항원 또한 감소를 초래한다. 비만은 여러 혈중 호르몬 수치에 이상변화를 일으켜 혈중 테스토스테론의 감소, 에스트로겐, insulin-like growth factor-1, insulin이 증가하고 테스토스테론 의 감소는 전립샘 성장에 주요 역할을 한다(Freedland 등, 2006). 혈청 내 에스트로겐과 인슐린을 증가시키고 성호르몬 결합 글로불 린과 자유테스토스테론을 감소시키며 성호르몬 결합 글로불린의 감소는 전립샘 내로의 안드로겐과 에스트로겐의 진입을 증가시키 고 전립샘 내부로 진입한 안드로겐은 안드로겐 수용체와 결합하여 전립샘을 증식시키게 된다. 또한 비만으로 증가된 인슐린은 전립샘 의 증식에 중요역할을 하는 IGF- 1 의 수용체와 결합하여 전립샘 증 식에 관여하고, 교감신경계의 과활성을 일으켜 하부요로증상의 악 화에도 영향을 미친다(Dahle 등, 2002). 손지철 등(2007)의 연구 에서는 건진센터를 방문한 사람들에게서 나이에 관계없이 체질량 지수(BMI)와 전립샘특이항원 수치는 음의 상관성을 갖는다고 하 였다. 지방세포는 테스토스테론을 에스트라디올로 변환시키는 주 요물질로 Eldrup 등(1987)은 낮은 체질량지수를 가진 남자가 더 높 은 혈청 테스토스테론을 나타낸다고 하였고, Banez 등(2007)은 전 립샘암으로 근치적 전립샘 적출술을 받은 환자를 대상으로 했던 연 구에서 체질량지수(BMI) 클수록 전립샘특이항원 수치가 낮게 측 정되는 것을 발견하고 이는 총 혈장량 증가에 의한 전립샘특이항원 수치의 상대적인 희석으로 추정하였다. 이 연구가 물론 전립샘암 환자를 대상으로 했기 때문에 정상 성인을 대상으로 한 연구와 직 접 비교할 수 없지만 비만에 의해 영향을 받는다고 알 수 있다. 또한 윤영은(2007)이 연구한 대사증후군과 전립샘특이항원 수치의 상 관관계에서 비만이 전립샘특이항원 수치를 감소시킨다는 결과와 함께 대사성 인자의 합이 많을수록 전립샘특이항원 수치가 낮았다 는 보고이다. 전립샘특이항원의 생성이 남성호르몬에 의해 촉진된 다는 것은 비만과 낮은 전립샘특이항원 수치와의 관계를 알 수 있 게 한다. 일부 연구 결과에 의하면 비만인 남성의 낮은 전립샘특이 항원은 검사의 민감도를 떨어뜨리고 전립샘암의 진단 시기를 늦추 게 되어 좋지 않은 예후를 나타냈다고 한다(Baillargeon 등, 2005; Barqawi 등, 2005). 일반적으로 전립샘의 이상 유무를 판단하는 전립샘특이항원의 절단치는 $4.0 \mathrm{ng} / \mathrm{mL}$ 이지만, Catalona 등 (2000)은 전립샘암 환자의 $20 \%$ 가 $2.6 \sim 4.0 \mathrm{ng} / \mathrm{mL}$ 범위에 있어 전 립샘특이항원 절단치를 $2.5 \mathrm{ng} / \mathrm{mL}$ 로 낮춰야 한다는 주장이 제기 되고 있는 가운데, 윤영은(2009)의 연구에서 전립샘특이항원 수치 가 $2.5 \mathrm{ng} / \mathrm{mL}$ 미만과 이상인 군으로 나누어 분석하였고, 대사증후 군중 비만이 전립샘특이항원수치가 $2.5 \mathrm{ng} / \mathrm{mL}$ 이상일 가능성을 낮추는 것으로 나타났다. 함영일 등(2009)는 성인남성의 인체측정 학적인자와 대사증후군 혈청학적인자가 전립샘특이항원에 미치
는 영향을 연구한 결과로 전립샘특이항원은 연령, $\mathrm{LDL}$ 콜레스테롤 에서 양의 상관관계와 대사증후군 인자들 중 중성지방과 음의상관 관계를 보였고, 체질량지수(BMI)와 유의한 음의 상관성을 보인 것 으로 나타났다. 고혈압은 혈중 테스토스테론을 감소시키고(Khan 등, 1988; Svartberg 등, 2004), 이로 인해 전립샘수치를 감소시킬 수 있다. 그러나, 고혈압은 전립샘특이항원 수치에 아무런 연관이 없다는 연구도 있다(Fukui, 2007). Werny 등(2006)은 당뇨 환자에 서 전립샘특이항원 수치가 $21.6 \%$ 낮으며 이러한 차이는 이환 기간 과 비례하여 당뇨로 진단받은 후 10 년이 지난 환자는 $27.5 \%$ 가 감 소하고 있음을 보여주고 있었다. 이는 당뇨환자에게서 성호르몬결 합글로불린(sex hormone-binding globulin; SHBG)이 낮기 때문 으로 연구 되었다(Barrett-Connor 등, 1990). 또한 몇몇 연구에서 도 공복 혈당이 전립샘특이항원 수치와음의 상관관계가 있음을 발 표하였다.

본 연구에서는 전립샘관련 환자들을 제외하기 위하여 통상적인 절단치인 $4.0 \mathrm{ng} / \mathrm{mL}$ 을 기준으로 사용하여 그 이상인 경우는 연구 대상에서 제외하였다. 정상 수치를 보이고 전립샘에 아무런 문제가 없는 사람을 대상으로 복부비만이 전립샘특이항원 수치에 영향을 미치는지 알아봄으로써 복부비만과 전립샘특이항원과의 관계에 대하여 밝혀보고자 하였다. 복부비만이 증가할수록 평균 전립샘특 이항원 수치가 유의하게 감소하였으며 이는 통계적으로 유의한 결 과를 보였다 $(p<0.05)$. 본 연구결과를 종합해보면 다른 연구 결과 들과 같이 비만이 남자의 전립샘 관련 건강에 유의하게 음의 영향 을 미치는 것으로 보이고, 단순 비만을 비롯하여 복부비만 역시 같 은 결과를 낳고 있다. 다시 말해서 비만인 경우에는 전립샘특이항 원에 미치는 영향에 대해 더 주의 깊은 관심이 필요하고, 추후 더 많 은 연구들로 복부비만이 전립샘특이항원에 더욱 깊은 관계를 보여 줄 필요가 있다.

본 연구는 남성의 복부비만과 전립샘특이항원 수치와의 연관성 을 보기위한 연구로 비만한 남성들에게서의 전립샘특이항원으로 보는 전립샘 관련 질병 예방관리에 도움이 되고자 하였다. 그러나 한 지역에 분포하는 사람들을 대상으로 하였고, 건강검진이라는 기 초데이터만을 이용하였기 때문에 후속 연구에서 좀 더 많은 변수를 이용해야 할 필요성이 있으며, 구체적이고 세부적인 자료로 연구해 야 깊이 있는 연구가 될 것이다. 또한 비만이 전립샘특이항원수치 에 얼마나 영향력을 미치는지 정확히 알 수 없어 전립샘특이항원수 치에 기준치를 어느 정도로 낮춰서 제시할 수 있는지 본 연구만으 로 알기 어렵다. 연구에서 가장 큰 아쉬운 점은 건강행태나 생활습 관을 포함하지 못하였다는 점으로 복부비만의 유무만을 가지고 전 립샘특이항원수치의 영향력을 설명하기엔 많이 부족하였다는 것 이다. 우리나라는 아직 전립샘 관련 연구가 많이 부족한 실정이다. 
서양의 연구결과가 우리나라를 대신 할 수 없다고 생각된다. 점점 고령인구가 늘어가는 시점에서 전립샘은 더 관심을 가져야 할 연구 라고 판단된다.

\section{Acknowledgements: None \\ Funding: None \\ Conflict of interest: None}

\section{References}

1. Barrett-Connor E, Khaw KT, Yen SS. Endogenous sex hormone levels in older adult men with diabetes mellitus. Am J Epidermiol. 1990, 132:895-901.

2. Banez LL, Hamilton RJ, Partin AW, Vollmer RT, Sun L, Rodriguez $\mathrm{C}$, et al. Obesity-related plasma hemodilution and PSA concentration among men with prostate cancer. JAMA. 2007, 298(22): 75-80.

3. Catalona WJ, Ramos CG, Carvalhal GF, Yan Y. Lowering PSA cutoffs to enhance of curable prostate cancer. Urology. 2000, 55(6):791-795.

4. Freedland SJ, Aronson Wj. Obesity and prostate caner. Urology. 2005, 65(3):433-439.

5. Fukui M, Ose H, Kitagawa Y, Yamazaki M, Hasegawa G, Yoshikawa T, et al. Relationship between low serum endogenous androgen concentrations and arterial stiffness in men with type 2 diabetes mellitus. Metavolism. 2007, 56(9):1167-1173.

6. Hahm YI, Joo KJ, Park HJ. The Effects of Anthropometric Factors and Serologic Factors of the Metabolic Syndrome on Prostate-Specific Antigen Levels in Korean Men. Korean Journal of Urology. 2009, 50(7):663-668.

7. Jeon HJ, Kim YS, Kang DR, Nam CM, Kim CI, Seong DH, et al. Age-Specific Reference Ranges for Serum Prostate-Specific Antigen in Korean Men. Korean Journal of Urology. 2006, 47(6):586-590.

8. Khan KT, Barrett-Connor E. Blood pressure and endogenous testosterone in men: an inverse relationship. J Hyertens. 1988, 150(4):329-332.

9. Lee CW. TheDiagnosticValueofPSA LevelChange AccoringtoBMIinBPH [Master Thesis]. 2010, p 4-5, Dong-A University, Busan.

10. Lee MJ, Park WH. Detection of Normal Serum Prostate Specific Antigen(PSA) Values according to Age in Healthy Korea Men without Prostatic Diseases. Korean J Clin Lab Sci. 2001, 33(2): 162-165.

11. Lee HJ, Kwon GS, Kim GT, Lee · KK. Orrelation between in- dicators of metabolic syndrome, WHR and \%Fat by BMI classification in adult men. The Korea Journal of Sports Science. 2004, 23(2):1027-1037.

12. Oesterling JE. Prostatic specific antigen: a critical assessment of the most useful tumor marker for adenocarcinoma of the prostate. J Urol. 1991, 145(90):7-23.

13. Ohori M, Wheeler TM, Dunn JK, Stamey TA, Scardino PT. The pathological features and progmosis of prostatic cancer detectable with current diagnostic test. JUrol. 1994, 152(2):1714-1720.

14. Park HS, Oh SW, Kang JH, Park YW, Choi JM, et al. Prevalence and Associated Factors with Metabolic Syndrome in South Korea-From the Korean National Health and Nutrition Examination Survey. 1998. Korean J Obes. 2003, 12:1-14.

15. Park SG, Lee YW, Kong MH, Kim HJ. The Comparison of Efficacy of Obesity Indices for Screening Metabolic Risk Factors Among Adults In Jeju Island. Korean J Obes. 2010, 19(3): 101-106.

16. Park HK, Hong SK, Byun SS, Lee SE. Comparison of the Rate of Detecting Prostate Cancer and the Pathologic Characteristics of the Patients with a Serum PSA Level in the Range of 3.0 to 4.0 $\mathrm{ng} / \mathrm{ml}$ and the Patients with a Serum PSA Level in the Range 4.1 to $10.0 \mathrm{ng} / \mathrm{ml}$. Korean Journal of Urology. 2006, 47(4):358-361.

17. Svartberg J, von Muhlen D, Schirmer H, Barrett-Connor E, Sundfjord J, Jorde R. Association of endogenous testosterone with blood pressure and left ventricular mass in men. The Troms study. Eur J Endocrinol. 2004, 150:65-71.

18. Shin KA, Kim HY, Kim NJ. Association between Exercise Capacity and Cardiovascular Risk Factors among Obesity Types in Adult Man. Korean J Clin Lab Sci. 2013, 45(3):96-101.

19. Sung WS, Jeon SH, Chang SG. The Effect of the Serum Cholesterol Level on the Clinicopathologic Characteristics of Prostate Cancer. Korean Journal of Urology. 2008, 49(2): 127-133.

20. Sohn JC, Lim MS, Chang HS, Park CH, Kim CI. The Association of Body Mass Index and Prostate-Specific Antigen. Korean Journal of Urology. 2007, 48(11):1121-1124.

21. Wang MC, Valenzuela LA, Murphy GP, Chu TM. Purification of a human prostate specific antigen. Invest Urol. 1979, 17(1): 59-63.

22. Werny DM, Sataiya M, Gregg EW. Prostate-specific antigen values in diabetic and nondiabetic US men, 2001-2002. AMJ Epidermiology. 2006, 164(9):78-83.

23. Yoon CJ, Moon KH, Park TC. Association between Obesity and Prostate Cancer. Yeungnam Univ. J. of Med. 2005, 22(2): 199-210.

24. Yoon YE. The Association between Metabolic Syndrome and Prostate-Specific Antigen Levels [Master Thesis]. 2009, p5-14, Hanyang University, Seoul. 